\title{
論文集予約購読申込書 正会員（個人）・準会員
}

論文集の購読を希望される方は、会費のほかに論文予約購読費が必要です。 論文予約購読費には 論文集および大会学術講演梗概集（CD-ROM版、冊子版梗概集）の代金が含まれております。 新規に 申込まれる場合、論文集の系列および冊子版梗概集（A1〜 F2）を選択してください。毎年 3 月 20 日 までに年間予約購読を申込まれた方は、その年の大会学術講演会の発表登録費が免除になります。

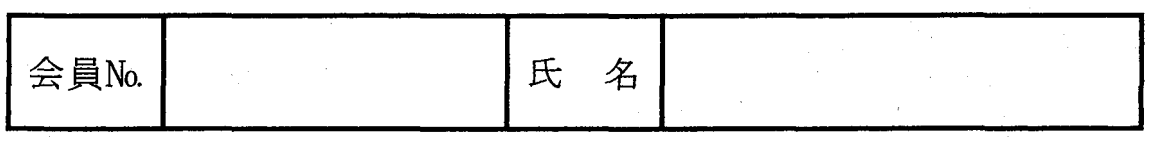

論文集＋大会学術講演梗概集（CD-ROM版、冊子版梗概集）

\begin{tabular}{|c|c|c|c|c|}
\hline \multirow{2}{*}{\multicolumn{2}{|c|}{$\begin{array}{c}\text { 論文集の選択 } \\
\text { ・希望する系列にレを記入して下さい }\end{array}$}} & \multicolumn{2}{|c|}{ 大会学術講演梗概集 } & \multirow{2}{*}{$\begin{array}{l}\text { 希望される区分にレ } \\
\text { を記入して下さい }\end{array}$} \\
\hline & & CD-ROM版 & 冊子版梗概集 & \\
\hline \multirow{2}{*}{1 系列 } & いづれかの 1 系列（論文集12冊） & \multirow{2}{*}{ 全分野 } & 1 分冊*または希望なし & $\square 12,000$ 円 \\
\hline & $\square$ 構造系 $\square$ 計画系 $\square$ 環境系 & & 12 分冊 & $\square 18,000$ 円 \\
\hline \multirow{2}{*}{2 系列 } & いづれかの 2 系列（論文集 24 冊） & \multirow{2}{*}{ 全分野 } & 1 分冊*または希望なし & $\square 12,600$ 円 \\
\hline & $\square$ 構造系 $\square$. 計画系 $\square$ 環境系 & & 12 分冊 & $\square 18,600$ 円 \\
\hline \multirow{2}{*}{3 系列 } & \multirow{2}{*}{$\square$ 全系列（論文集36冊） } & \multirow{2}{*}{ 全分野 } & 1 分冊*または希望なし & $\square 13,200$ 円 \\
\hline & & & 12 分冊 & $\square 19,200$ 円 \\
\hline
\end{tabular}

冊子版梗概集の選択

（＊1分冊を選択された方は下記より1つだけ選び、数字に○をつけて下さい）

\begin{tabular}{|c|c|}
\hline \multicolumn{2}{|r|}{ 梗概集 } \\
\hline 0 . 希望なし & CD-ROM版のみ（構造系、計画系、環境系の全分野を掲載） \\
\hline 1. A-1 & 材料施工 \\
\hline 2. A-2 & 防火、海洋、情報システム技術 \\
\hline 3. B-1 & 構造 I : 渮重・信頼性、応用力学・構造解析、基整構造、シェル：空間構造 \\
\hline 4. B-2 & 構造 II :振動、原子カプラント \\
\hline 5. C-1 & 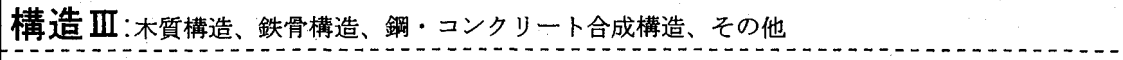 \\
\hline 6. C-2 & 構造IV:鉄筋コンクリート構造、プレストレストコンクリート構造、壁式構造・組積造 \\
\hline 7. D-1 & 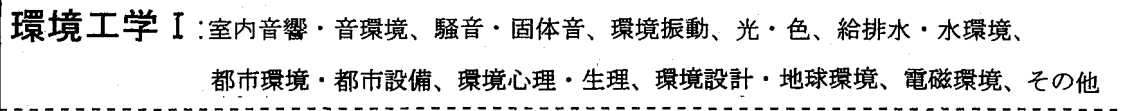 \\
\hline 8. D-2 & 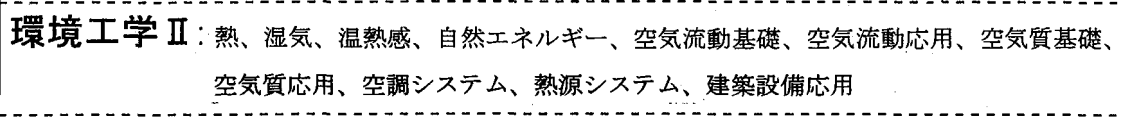 \\
\hline 9. E-1 & 建築計画 I :各種建物・地域施設、設計方法、粠法計画、人間工学、計画基礶 \\
\hline 10. E-2 & 建築計画 II 住居・住環境、農村計画、教育 \\
\hline 11. F-1 & 都市計画、建築経済－住宅問題 \\
\hline 12. F-2 & 建築歴史・意匠 \\
\hline
\end{tabular}

